\title{
Evaluation effects of ascorbic acid leads to activate and induce osteogenic protein marker expression: in silico and in-vitro study
}

\author{
Imam Rosadi ${ }^{1, *}$, Feldiana Tuesrilia Indrady ${ }^{1}$, Karina Karina ${ }^{2,3,4}$, Nova Hariani ${ }^{1,5}$
}

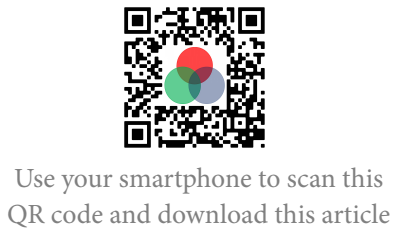

${ }^{1}$ Department of Biology, Faculty of Mathematics and Natural Sciences, Mulawarman University, Kalimantan Timur, Indonesia

${ }^{2}$ HayandraLab, Yayasan Hayandra Peduli, Jakarta, Indonesia

${ }^{3}$ Faculty of Medicine, Universitas Pembangunan Nasional Veteran Jakarta, Indonesia

${ }^{4}$ Pusat Kajian Stem Cell, Universitas Pembangunan Nasional Veteran Jakarta, Indonesia

${ }^{5}$ Research Center for Natural Products from Tropical Rainforest (PUI-PT OKTAL)

\section{Correspondence}

Imam Rosadi, Department of Biology, Faculty of Mathematics and Natural Sciences, Mulawarman University, Kalimantan Timur, Indonesia

Email: imamrosadi@unmul.ac.id

History

- Received: Sep 11, 2021

- Accepted: Dec 25, 2021

- Published: Jan 23, 2022

DOI : 10.15419/bmrat.v9i1.720

\section{Check for updates}

\section{Copyright}

(c) Biomedpress. This is an openaccess article distributed under the terms of the Creative Commons Attribution 4.0 International license.

\begin{abstract}
Background: Mesenchymal stem cells (MSCs) are multipotent cells that can differentiate into several cell types including chondrocytes and osteocytes. The process of differentiation into such tissues is aided by transcription factors and collagen gene markers. Collagen biosynthesis is influenced by the presence of vascular endothelial growth factor (VEGF) and ascorbic acid cofactors of the prolyl hydroxylase 2 (PHD2) enzyme found in human cell receptors. The focus of this study is evaluation of how in silico methods can elucidate the effect of ascorbic acid on PHD2 and its expression. This study aimed to evaluate the role of ascorbic acid in its interaction with PHD2 (in silico) and the expression of type 1 collagen (COL1), type 2 collagen (COL2), and VEGF. Methods: The technique of in silico molecular docking consisted of three steps: preparation of PHD2 receptors using AutoDock tools, preparation of ligand ascorbic acid using AutoDock tools, and molecular docking using AutoDock Vina. The results of in silico molecular docking were visualized using py$\mathrm{MOL}$ and BIOVIA discovery studio. Furthermore, in vitro MSCs from adipose tissue were isolated and characterized based on protein marker expression. The effect of ascorbic acid supplementation (50 and $100 \mu \mathrm{g} / \mathrm{mL}$ ) on stem cell differentiation was evaluated based on the mRNA ratio of VEGF/COL1, VEGF/COL2, and COL2/COL 1. Results: Molecular docking of ligand ascorbic acid with PHD2 resulted in nine poses. The third pose was chosen because it had an affinity of $-5.7 \mathrm{kcal} / \mathrm{mol}$ and a root-mean-square deviation (RMSD) of 1.96, indicating a valid docking result. Meanwhile, the 2D conformer showed van der Waals bonds on Tyr303 and Try329 residues. MSCs were differentiated into adipocytes, chondrocytes, and osteocytes. Regarding the marker ratio of gene expression, at $50 \mu \mathrm{g} / \mathrm{ml}$ ascorbic acid there was an increase in the VEGF/COL1 and VEGF/COL2 ratios and a decrease in the COL2/COL 1 ratio compared with the control; at $100 \mu \mathrm{g} / \mathrm{ml}$ ascorbic acid there was a decrease in both ratios (VEGF/COL1 and COL2/COL 1), and the VEGF/COL2 ratio continued to increase. Conclusions: In silico molecular docking between PHD2 and ascorbic acid, which was studied via bioinformatics, resulted in a stable interaction with good ligand position. Further in vitro studies would support the influence of ascorbic acid on transcription factors, collagen gene markers, and the differentiation of MSCs.
\end{abstract}

Key words: ascorbic acid, mesenchymal stem cells (MSCs), prolyl hydroxylase

\section{INTRODUCTION}

Mesenchymal stem cells (MSCs) are cells that can differentiate with multipotent properties ${ }^{1}$. MSCs can differentiate into several types of cells, including chondrocytes, osteoblasts, myoblasts, and adipocytes. MSCs are found in adult tissues such as fat tissue and bone marrow ${ }^{2}$. They are reported to have antitumor properties; one of the derivatives of these MSCs, TGF- $\beta 1$, has a role in response to metastasis. Therefore, MSCs are important for research and further applications because they have the potential for tumor cell control ${ }^{3}$. Adipose-derived stem cells (ASCs) are also stem cells that can differentiate into various types of cells, including chondrocytes ${ }^{4}$. The process of cartilage formation begins with the differentiation of MSCs into chondrocytes; transcription factors such as sox 6 and $c b f a 1$ contribute to the production of COL1A1, COL2A1, and aggrecan enhancers ${ }^{5,6}$.

According to previous research, the expression of the sox 5 , sox 6 , and sox 9 genes stops once the hypertrophic chondrocytes are formed ${ }^{7}$. The role of CBFA1 in the development of cartilage cells is to stimulate the differentiation of hypertrophic chondrocytes into bone matrices ${ }^{5}$. Ascorbic acid compounds act as induction factors and growth factors that differentiate MSCs into osteocytes. Differentiation to chondrocytes requires a TGF- $\beta$ induction factor ${ }^{6}$. Stem cells can repair damage by homing through blood vessels, a process that involves molecular mechanisms that induce neovascularization in damaged tissues. Factors that affect stem cells are microenvironments associated with increased expression of vascular endothelial growth factor (VEGF). The process of differen- 
tiating stem cells into bone tissue is associated with proteins. According to Katili (2009) ${ }^{8}$, a protein is a macromolecule involved in the growth and development of humans. Collagen is a protein that plays a role in the formation of bone tissue. Collagen structure is composed of tropocollagen, microfibrils, and a covalent skeleton between hydroxylysine and hydroxyproline residues. Hydroxylysine plays an important role in the formation of collagen fibers.

The formation of amino acid residues hydroxylysine and hydroxyproline is influenced by the presence of ascorbic acid (vitamin C). In cells, ascorbic acid interacts with prolyl hydroxylase enzymes to convert proline residues into hydroxyproline in collagen ${ }^{8}$. Ascorbic acid is a vitamin that acts as a non-heme activator of $\alpha$-ketoglutarate dioxygenases in collagen and hypoxia-inducible factor prolyl hydroxylases (HIFPHD). Hydroxylation of proline stabilizes the structure of collagen ${ }^{9}$. In the process of cell metabolism, ascorbic acid is not directly synthesized as one of the organic substances required by the body. However, ascorbic acid is required in small amounts. Due to its water-soluble properties, ascorbic acid will affect the differentiation of body tissues such as bone tissue; as an antioxidant, it plays an active role in collagen synthesis, from thyroxine decomposition to proline hydroxylation ${ }^{10}$. According to Astawa et al. (2020) ${ }^{11}$, ascorbic acid acts as a cofactor that binds to the enzymes proline hydroxylase and lysine hydroxylase. Both enzymes are involved in the biosynthesis of COL1 and bone matrix. Therefore, the ascorbic acid that enters the body will be involved in the healing process of bones. This study aimed to evaluate the interaction between prolyl hydroxylase 2 (PHD2) receptor and ligand ascorbic acid via in silico analysis and to determine the affect of different concentrations of ascorbic acid on the differentiation of chondrocyte and osteocyte stem cells based on expression mRNA markers COL1, COL2, and VEGF.

This study focuses on evaluating how in silico methods can elucidate the effect of ascorbic acid on PHD2 and its expression. According to Reang et al. (2021) ${ }^{\mathbf{1 2}}$, the latest research suggests that ascorbic acid has potential as an antitumor therapy. Based on that research, several studies have reported that ascorbic acid derivatives in hydroxyl groups can be substituted with certain substituents in vitro to alter antitumor activity. Other studies suggest that ascorbic acid can be used as an antitumor therapy. Therefore, some challenges and problems need to be developed further based on this topic, whether ascorbic acid and osteogenic protein marker expression also significantly affect tumor growth. As a recommendation for further research, this study will first describe the interaction between ascorbic acid and prolyl hydroxylase (PHD) in silico and their effects in vitro on collagen protein markers such as COL1, COL2, and VEGF. We hope that this research can address these questions.

\section{METHOD}

\section{Receptor preparation}

The prolyl hydroxylase 2 (PHD2) protein with Protein Data Bank (PDB) ID 2G19 9 was obtained for receptor preparation using PDB AutoDock tools 4.2.6 as software. The preparation started with a displayed receptor in pdb format. Kollman charges and polar hydrogen molecules were added, and water molecules were eliminated. Then, the receptor was used as a macromolecule in the menu section of the grid. The results of the receptor preparation were stored in PDBQT format.

\section{Ligand preparation}

The compound L-ascorbic acid 2-phosphate (ID 54679073) interacted with the receptor as a ligand. This compound was obtained in SDF format from the database. AutoDock tools 4.2.6 software was used for ligand preparation. First, the ligand was converted from SDF to PDB format using pyMOL software. The preparation started with a displayed ligand file (PDB format). Next, Gasteiger charges and all hydrogen molecules were added, and hydrogen was separated. L-ascorbic acid 2-phosphate was used as a form ligand. Ligand setup included detecting root, choosing root, choosing torsion, and number torsion. The results of ligand preparation were saved in PDBQT format.

\section{Molecular docking}

Molecular docking required three steps. In the first step, AutoDock tools 4.2.6 was used to display receptor and ligand files in PDBQT format. Then, the receptor was selected as a macromolecule and a grid box was set up. The grid box value was saved in .txt format. The created config note (.txt format) contained the file name of the receptor, file name of ligand, center value, size value of the three variable grid dimension results, and exhaustiveness as Vina parameters.

The second step was to use AutoDock Vina and a command prompt. Insert the docking location format folder and enter. Next, insert the Vina location format folder with the command prompt formula that is vina - config config.txt - log log.txt and waited a while and get the output docking results. In the third 
step, pyMOL software was used to visualize 3D models of the results of receptor and ligand docking. Finally, interactions between molecules were visualized with 2D models using BIOVIA Discovery Studio software.

\section{Donor}

The study was conducted in accordance with the Declaration of Helsinki (2013 revision). The liposuction protocol was approved by the ethical committee of Dharma Nugraha Hospital (No. 001/SkeIKom/RSDN/I/2020) and informed consent was obtained from the participant.

\section{Mesenchymal stem cell (MSC) isolation}

Adipose tissue was isolated from one donor at the age of 46 . The tissue was enzymatically digested using the $\mathrm{H}$-Remedy protocol for $1 \mathrm{hr}$ at $37^{\circ} \mathrm{C}$, as previously reported $^{13,14}$. To inactivate the enzyme, Dulbecco's Modified Eagle's Medium (DMEM) containing 1,000 $\mathrm{mg} / \mathrm{L}$ glucose and $4 \mathrm{mM}$ l-glutamine (Gibco, USA) was added, followed by centrifugation for $5 \mathrm{~min}$ at $600 \times \mathrm{g}$. The pellet was then washed using saline and centrifuged to obtain cell pellets. The pellet containing stem cells was cultured at $37^{\circ} \mathrm{C}$ with $5 \% \mathrm{CO}_{2}$ to expand the cells. After the cell culture reached $80 \%$ confluency, the cells were harvested enzymatically using Tryple Select (Gibco, USA).

\section{Multipotency assay}

Passage 3 of the MSCs was cultured at $5 \times 10^{3}$ cells/well in DMFA medium containing DMEM (Gibco, USA), 10\% fetal bovine serum (Biowest, USA), and 100X antibiotic-antimycotic (Gibco, USA). After every $2-3$ days of observation, the medium was refreshed. When the confluency exceeded $80 \%$, the medium was replaced with StemPro differentiation kit (Gibco, USA) for chondrogenic, osteogenic, and adipogenic lines for 14 days. The cells were then fixed in $4 \%$ paraformaldehyde. Adipocytes, chondrocytes, and osteocytes were stained with Oil Red O, alcian blue, and alizarin red, respectively, and observed using an inverted microscope (OPTICA, Italy).

\section{Ascorbic acid supplementation}

Cells were seeded and cultured in T-25 flasks $\left(5 \times 10^{3}\right.$ cells/well) for 5 days. We analyzed the effect of ascorbic acid supplementation. The control medium was DMFA and ascorbic acid groups were supplemented with $50 \mu \mathrm{g} / \mathrm{mL}$ and $100 \mu \mathrm{g} / \mathrm{mL}$ of ascorbic acid (Sigma, USA). After 5 days of culture, the cells were observed and harvested for further analysis.

\section{mRNA expression}

RNA isolation was performed using the SV Total RNA Isolation System (Promega, USA), while synthesis cDNA and mRNA expression analysis were performed using the GoTaq 2-Step RT-qPCR System (Promega, USA), following manufacturer instructions. We analyzed COL1, COL2, and VEGF with glyceraldehyde-3-phosphate dehydrogenase (GAPDH) as a reference gene (Table 1). The cycle condition was an initial denaturation step of $95^{\circ} \mathrm{C}$ for $2 \mathrm{~min}$, followed by 40 cycles of denaturation at 95 ${ }^{\circ} \mathrm{C}$ for $15 \mathrm{~s}$, annealing at $54.4{ }^{\circ} \mathrm{C}$ for $1 \mathrm{~min}$, and a final extension at $60-95^{\circ} \mathrm{C}$ for $5 \mathrm{~s}$. The qPCR results were analyzed following the $2^{-\triangle \Delta C T}$ method described by Livak and Schmittgen ${ }^{15}$.

\section{Statistical analysis}

The data from each parameter was presented as average \pm standard deviation. Significance tests were performed using the analysis of variance (ANOVA) test. A significant difference was determined if the $p$-value less than 0.05 .

\section{RESULTS}

\section{Molecular docking}

Figure 1 shows the results of docking completed using AutoDock software and AutoDock Vina. The pyMOL software displayed the docking results as an illustration, with blue shapes representing the PHD2 protein as the receptor and red and orange shapes representing ascorbic acid as the ligand (Figure 1). The results of the molecular docking of ascorbic acid compounds against PHD2 (2G19) receptors obtained nine configurations with varying affinity and root-mean-square deviation (RMSD) values. Molecular docking showed an affinity of $-5.7 \mathrm{kcal} / \mathrm{mol}$ and RMSD value of 1.96 (Figure 1).

Data interaction between receptor and ligand is shown in Figure 2. The results of the $2 \mathrm{D}$ conformer molecular docking between ligand ascorbic acid and receptor 2G19 illustrates the presence of van der Waals bonds between Tyr303 and Try329 residues. In addition to the presence of van der Waals bonds, there are various bonds and interactions between other amino acid residues (Figure 2): waterhydrogen bonds at amino acid residues to 602, 653, and 617; conventional hydrogen bonds on at residues Tyr303 and Tyr329; and a salt bridge at the Arg383 residue.

According to Gandu et al. (2021) ${ }^{\mathbf{1 6}}$, low affinity values indicate a more stable interaction between ligands and receptors. Meanwhile, according to Saputra 


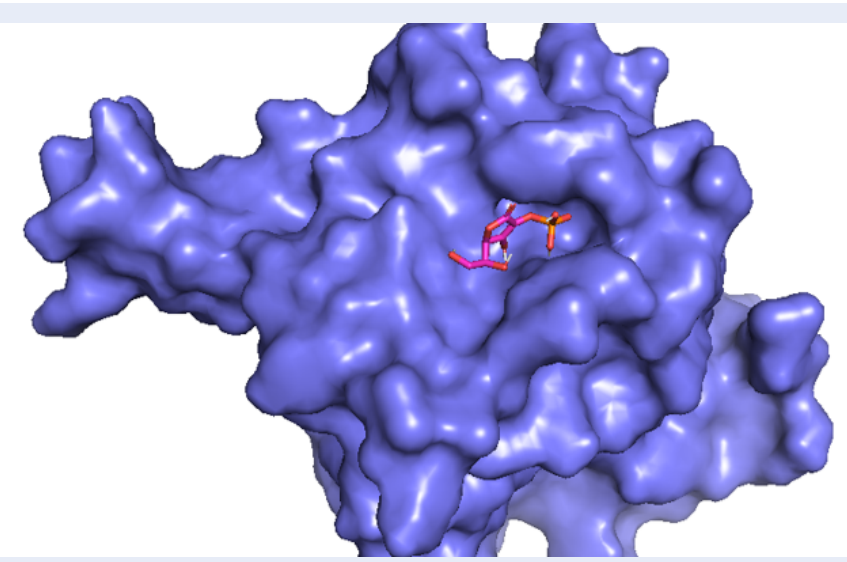

Figure 1: Visualization of molecular docking in 3D conformer. The red color represents ascorbic and while the blue surface represents the PHD2 protein (pyMOL software).

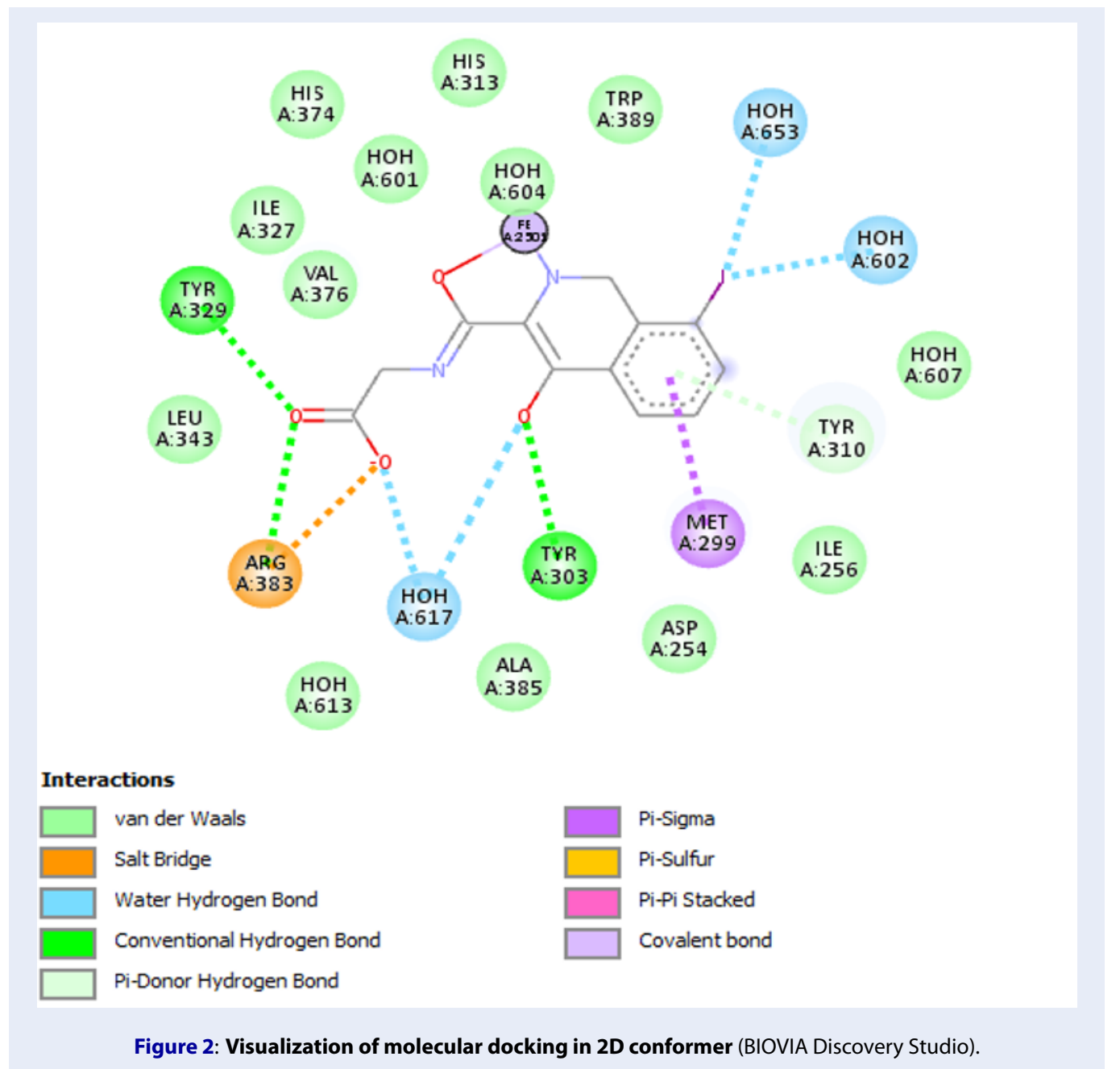




\begin{tabular}{llll}
\hline Table 1: Primer design & & \\
\hline Genes & & Nucleotide base $\left.\mathbf{( 5}^{\prime}-\mathbf{3}^{\prime}\right)$ & Base number \\
\hline GAPDH & forward & CAAGAGCACAAGAGGAAGAGAG & 22 \\
& reverse & CTACATGGCAACTGTGAGGAG & 22 \\
VEGF & forward & GAGCTTCCTACAGCACAACA & 20 \\
& reverse & CCAGGACTTATACCGGGATTTC & 22 \\
COL2 & forward & GAACCCAGAAACAACACAATCC & 22 \\
& reverse & CATTCAGTGCAGAGTCCTAGAG & 21 \\
\hline COL2 & forward & AGAGTGGAGCAGTGGTTACTA & 21 \\
& reverse & GATACAGGTTTCGCCAGTAGAG & 22 \\
\hline
\end{tabular}

(2018) ${ }^{17}$, the RMSD value is valid if it is $\leq 3^{\prime}$, where a lower value indicates better conformation of the ligands. Ascorbate is a ligand that interacts directly with LEPREL1 or PHD2, a receptor (Figure 3). Ascorbate and LEPREL1 also interact with COL1 (COL1A1), an osteogenic marker. COL2 (COL2A1) is a chondrogenic marker that does not interact directly with ascorbate. Transcription factors involved in collagen biosynthesis include SMAD2, SMAD3, SMAD4, and TGFBR1. VEGFA is VEGF as a compound that affects the differentiation of stem cells into adult tissues, namely chondrocytes.

\section{Morphology of the cells}

The morphology of cells isolated from fat tissue was a fibroblast-like shape that was anchored to the bottom plate (Figure 3). The cells were captured on day 4 using an inverted microscope (Optilab, Nikon). The shape of the cells was conserved at a similar spreading size.

\section{Multipotency assay}

The cells were induced in the specific medium and identified by lipid droplets (adipogenesis), blue micromass-like structure (chondrogenesis), and mineralization (osteogenesis). Passage 2 cells were characterized by multipotency. The results showed that the isolated cells from adipose tissue differentiated into adipocytes, chondrocytes, and osteocytes (Figure 4 A-C).

\section{mRNA expression}

The VEGF/COL1 ratio increased from a value of 1.00 in the control to 1.30 at $50 \mu \mathrm{g} / \mathrm{ml}$ ascorbic acid, and decreased to 0.73 at $100 \mu \mathrm{g} / \mathrm{ml}$ ascorbic acid (Figure 5). The VEGF/COL2 ratio increased significantly from 1.00 to 2.59 and decreased to 1.92 .
The ratio of COL2/COL1 decreased from 1.00 to 0.50 and 0.38 , respectively. The decreasing ratio of COL2/COL1 indicated the stem cell differentiation lead to osteogenic differentiation.

\section{DISCUSSION}

Prolyl hydroxylase (PHD) is an enzyme that plays a role in post-translation. In humans, two types of PHD enzymes are induced by hypoxia-inducible factor (HIF) to influence the hypoxia response and proline modification of collagen. Hypoxia is a nonphysiological, low level of oxygen and is a common phenomenon in most tumors. Hypoxia response confers treatment resistance in cancer cells by regulating processes that include the protection of the cells from external stress and the control of autophagy. The 3D conformation of L-ascorbic acid 2-phosphate $\left(\mathrm{C}_{6} \mathrm{H}_{9} \mathrm{O}_{9} \mathrm{P}\right)$ is shown in Figure $6 \mathbf{B}$.

HIF is a transcription factor consisting of the $\mathrm{O}_{2}$ sensitive molecules $\alpha$ and $\beta$, and a constitutive subunit, which are helix-loop-helix protein domains. HIF stability is regulated in hif $\alpha$ prolyl hydroxylation post-translation processes, where the reaction is catalyzed by the HIF domain PHD protein. This protein belongs to the group of non-heme iron $\left(\mathrm{Fe}^{I I}\right)$ dioxygenase enzyme cofactors of $\mathrm{O}_{2}$ molecules. There are three known PHD isoforms: PHD1 is found in the testes, brain, kidneys, heart, and liver; PHD2 is found in the network area; and most PHD3 is found in the heart ${ }^{18}$. The PHD protein has four alpha-helix structures and five beta-sheets (Figure $6 \mathbf{A}$ ). The structure of this enzyme is an $\alpha_{2} \beta_{2}$ tetramer. The $\alpha$ subunit consists of an $\mathrm{N}$-terminal substrate-binding domain and the C-terminal catalytic domain for proline hydroxylation; the $\beta$ subunit supports the alpha subunit ${ }^{19}$. According to Gandu et al. (2021) ${ }^{\mathbf{1 6}}$, low affinity values indicate a more stable interaction between ligands and receptors. According to Saputra (2018) ${ }^{17}$, 


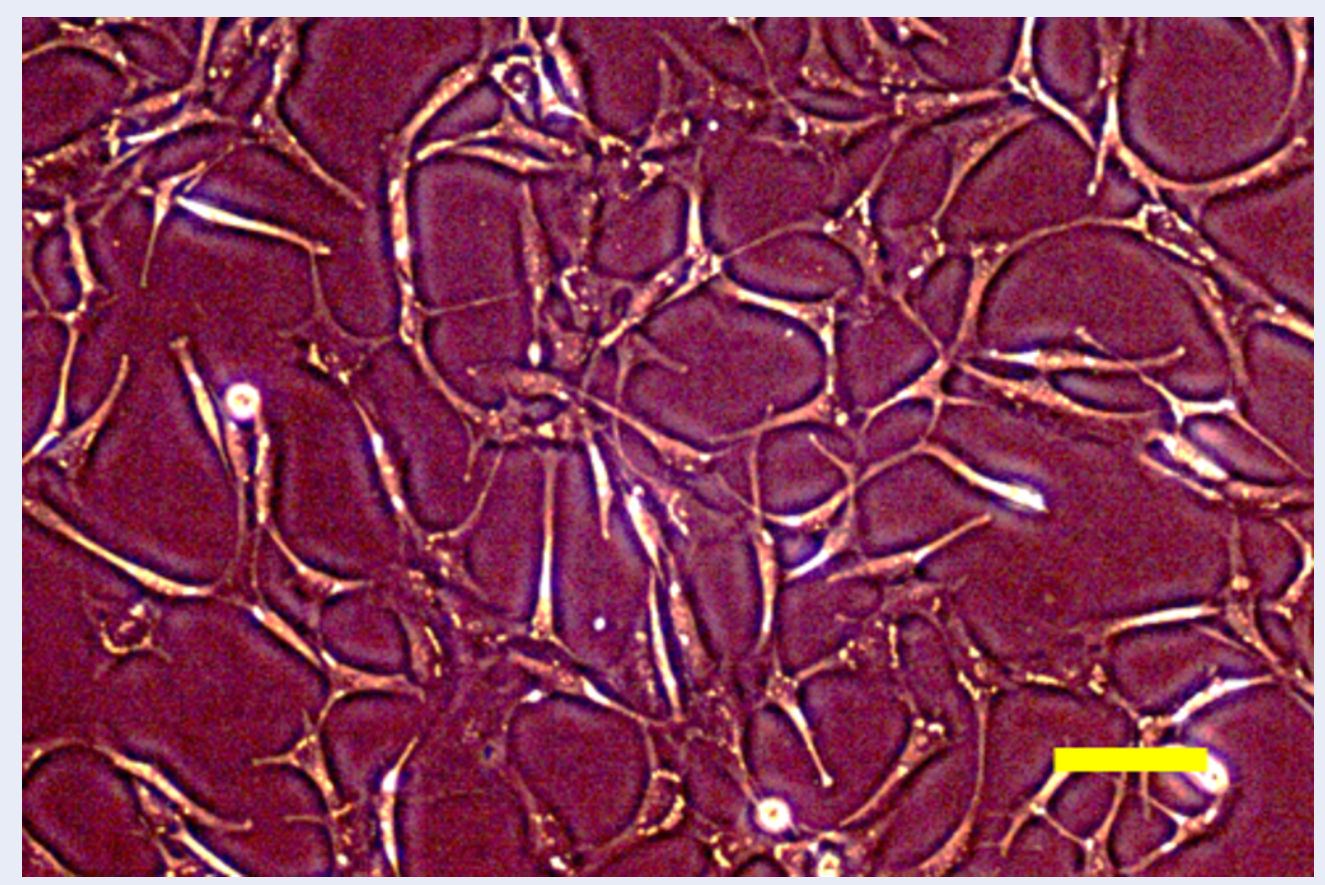

Figure 3: The cells showed fibroblast-like morphology on day 4 of culture (yellow bar $=100 \mu \mathrm{m})(\mathrm{Optilab}$ Microscope, Nikon, Italy).

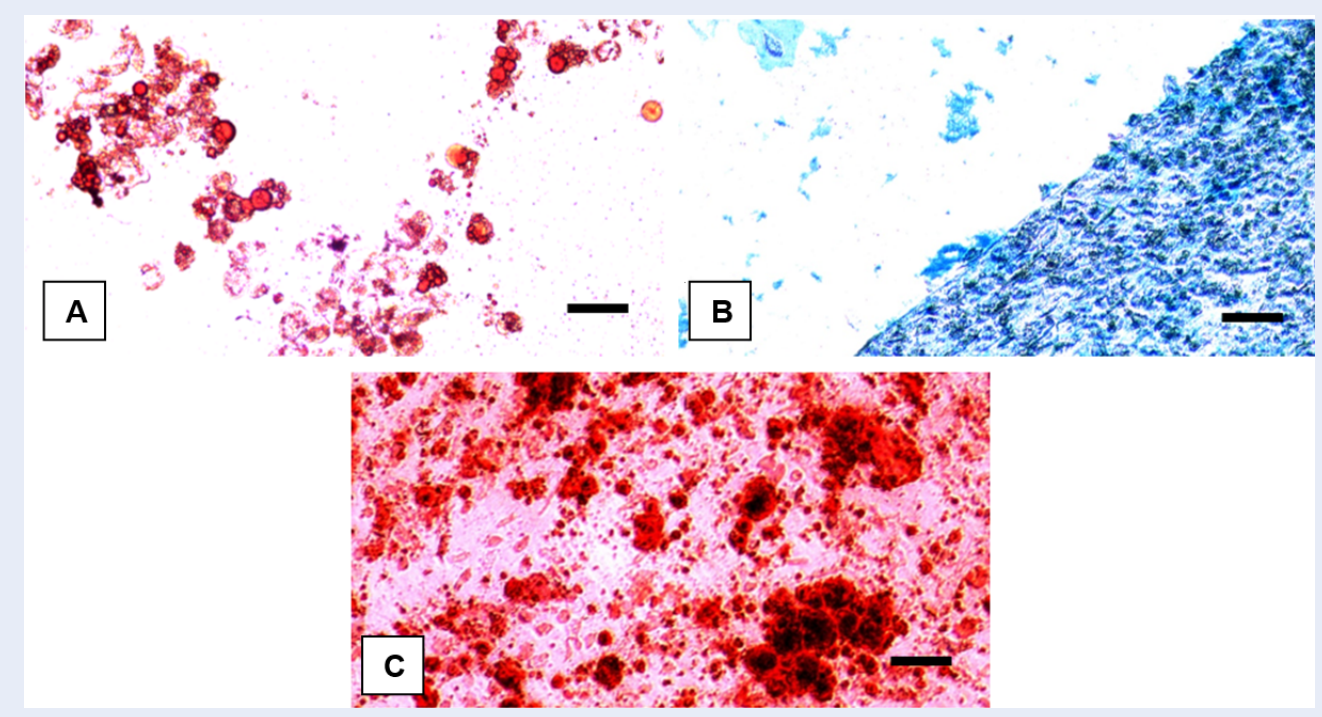

Figure 4: Multipotency assay of isolated cells from adipose tissue. The cells were differentiated into: adipocytes, indicated by lipid droplets $(\mathbf{A})$; chondrocytes, indicated by blue staining (B); and osteocytes, where red staining indicated mineralization (C) (black bar $=100 \mu \mathrm{m}$ ) (Optilab Microscope, Nikon). 


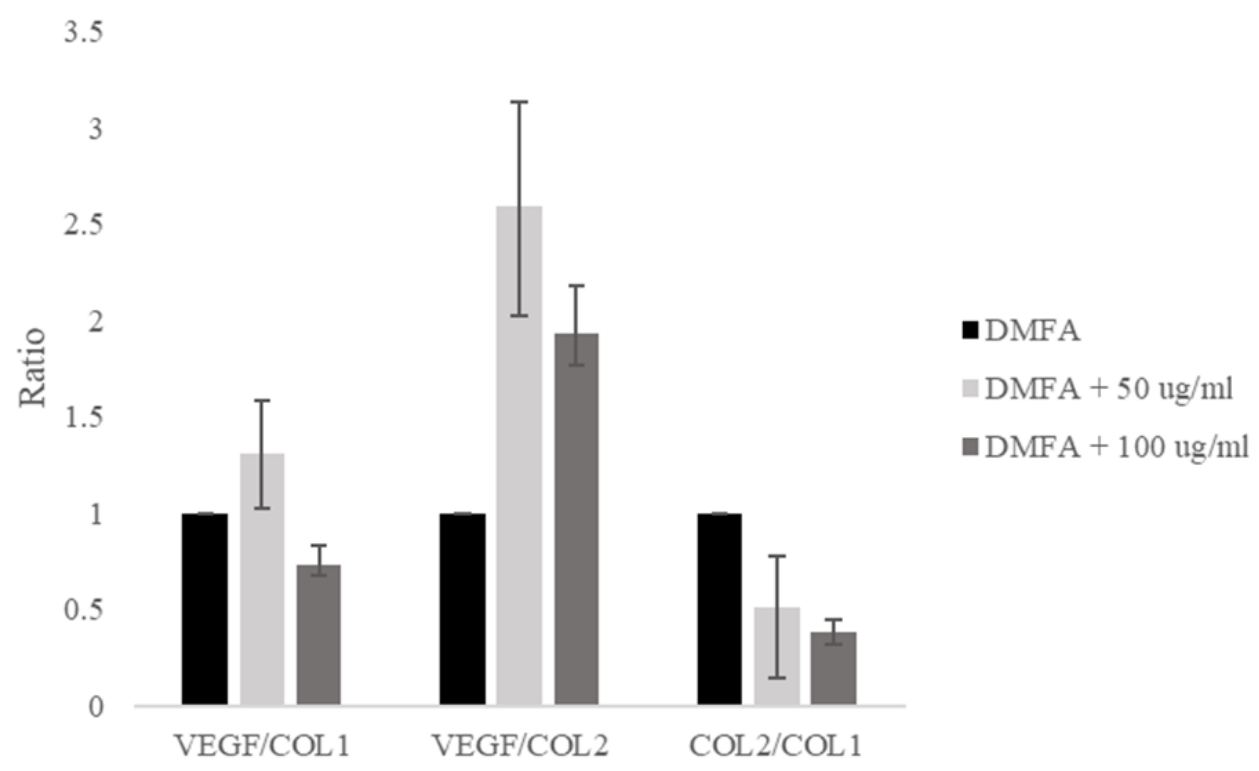

Figure 5: Gene expression ratio of markers VEGF/COL1, VEGF/COL2, and COL2/COL1.

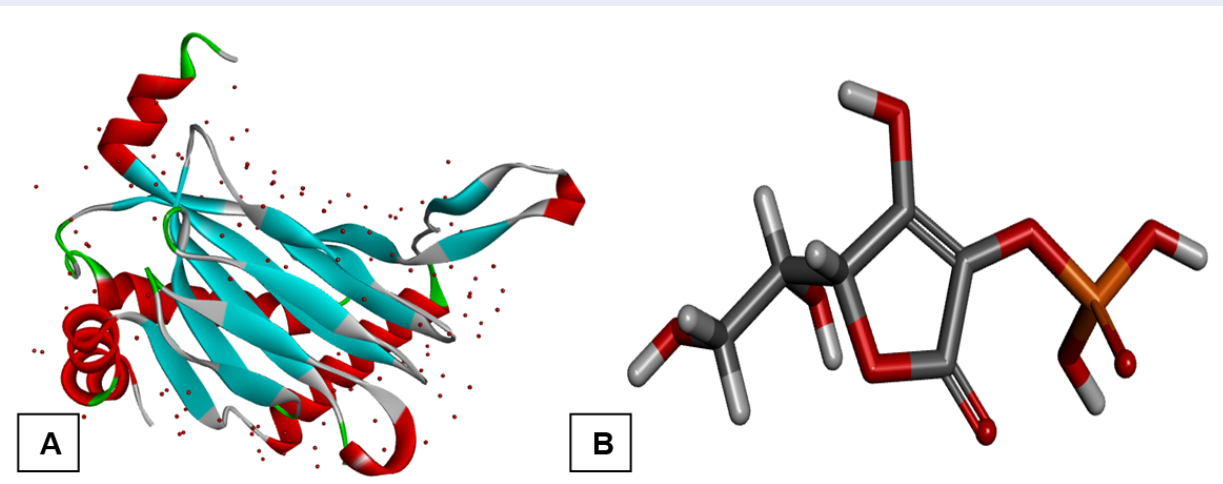

Figure 6: Ligand and receptor preparation. The 3D conformation of prolyl hydroxylase 2 (PHD2) (A) and Lascorbic acid 2-phosphate (B).

the value of RMSD (Root Mean Square Deviation) is valid if obtained $\leq 3^{\prime}$ where the smaller the value, the better the pose of ligands. The results of Osipyantsa et al. (2019) ${ }^{9}$, showed that the docking area between ascorbic acid and PHD2 lies at residue Tyr310.

Ascorbic acid acts as a cofactor for lysine and proline hydroxylase, which both play a role in collagen biosynthesis. Ascorbic acid is a cofactor in processes of the transcription and translation because it is associated with the expression of mRNA for the production of collagen ${ }^{20}$. Ascorbic acid can suppress the activation of HIF PHD. HIF and alpha-ketoglutarate $(\alpha \mathrm{KG})$ inhibitors are less sensitive to ascorbic acid suppression at certain concentrations. The result of docking ascorbic acid with HIF PHD2 is interference in one of the regions. Therefore, while ascorbic acid is a cosubstrate of HIF PHD that can compete for $\alpha \mathrm{KG}$ binding sites at the active site of enzymes, it cannot inactivate enzymes ${ }^{9}$.

The current computational method has been used to investigate the structure and properties of molecules through the visualization and modeling of moleculee. Computational methods, or the in silico technique, can be used to predict the interaction and bonding of a compound with its target protein, predict compound affinity, and display visualization from the ac- 
tive side through molecular docking ${ }^{21}$. Based on in silico study, we evaluated the role of ascorbic acid in MSC differentiation using adipose-derived stem cells (ASCs).

The isolated cells were fibroblast-like in shape and could differentiate into adipocytes, chondrocytes, and osteocytes, which indicated that the cells were $\mathrm{MSCs}^{22}$. A previous study reported that adipogenesis was indicated by lipid droplets, while chondrogenesis and osteogenesis were indicated by micromass-like structure and mineralization stained by alcian blue and alizarin red $\mathrm{O}$, respectively ${ }^{6,23}$. MSCs were then supplemented with ascorbic acid to evaluate the differentiation lineage. Based on the in silico interaction, the chondrogenic and osteogenic differentiation lineage of MSCs were evaluated.

Several proteins have roles in chondrogenic differentiation, including COL2, transforming growth factorbeta (TGF- $\beta$ ), SMAD2, SMAD3, SMAD4, SOX9, aggrecan, and glycosaminoglycans (GAGs), while osteogenic differentiation includes COL1, RUNX2, type 10 collagen, and mineralization (calcium deposition) ${ }^{6}$. Vascular endothelial growth factor (VEGF) as a marker plays a role in osteoarthritis (OA) and bone growth after birth. Increase in VEGF expression correlates with OA severity and causes inflammation in OA that correlates with expression of COL1A1. Chondrocytes that are deficient in HIF become hypertrophic, which affects ossification, expression of COL2, and induces apoptosis of the chondrocyte ${ }^{24}$. In this study, the expression ratios of VEGF/COL1, $V E G F / C O L 2$, and COL2/COL1 were evaluated. According to Shaw N \& Högler W (2018) ${ }^{25}$, COL1 is the most abundant protein synthesized by osteoblasts. According to P.Mansell J \& J.Bailey A (2004) ${ }^{\mathbf{2 6}}$, COL2 is the major supporting collagen of articular cartilage. The results indicate that ascorbic acid induces osteogenic differentiation. At a concentration of 50 $\mu \mathrm{g} / \mathrm{ml}$ ascorbic acid, the ratio of VEGF/COL1 and $V E G F / C O L 2$ were the highest compared with other groups. The supplementation of $100 \mu \mathrm{g} / \mathrm{ml}$ ascorbic acid induced rapid osteogenic differentiation, indicated by the lowest COL2/COL1 expression ratio compared with the control and supplementation of $50 \mu \mathrm{g} / \mathrm{ml}$ ascorbic acid. We demonstrated that ascorbic acid interacts with PHD2 to initiate COL1 production and induces osteogenic differentiation based on in silico and in vitro studies. However, we evaluated only a small number of chondrogenic and osteogenic marker proteins.

\section{CONCLUSION}

In conclusion, MSCs are differentiated cells with multipotency in bone and adipose tissue. One of the bone tissues, specifically chondrocytes, begins in the formation of MSCs and transcription, which will be expressed by a gene into mRNA and then into protein. Collagen is a protein that plays a role in the formation of bone tissue. Ascorbic acid induces the formation of collagen structures. This research was conducted in silico and in vitro to determine the ligand-receptor interaction, the concentration of ascorbic acid that affects MSCs, and its effect on the expression of protein markers. PHD2 is the enzyme responsible for the hypoxic response that is commonly found in tumor cells. The results of molecular docking between PHD2 receptor and ascorbic acid ligand showed an affinity interaction of $-5.7 \mathrm{kcal} / \mathrm{mol}$, which indicated a fairly stable interaction, and an RMSD value of 1.96 , which indicated the better the ligand position. Specifically, these receptors and ligands are shared by van der Waals at residues Tyr202 and Tyr329. An additional in silico study demonstrated a close interaction of ascorbic acid and LEPREL1, with COL1A1 and COL2A1 as markers of protein expression. Furthermore, VEGF affected the differentiation of MSCs isolated from adipose tissue. Therefore, this research must be further developed to elucidate the relationship between ascorbic acid and other MSC derivatives involved in antitumor processes.

\section{ABBREVIATIONS}

ASCs: Adipose-derived stem cells, COL1: type 1 collagen, COL2: type 2 collagen, HIF-PHD: hypoxiainducible factor prolyl hydroxylases, MSCs: Mesenchymal stem cells, PHD2: prolyl hydroxylase 2, VEGF: vascular endothelial growth factor

\section{ACKNOWLEDGMENTS}

We are greatly indebted for the cooperation of the lipoaspirate donors for their lipoaspirate donation.

\section{AUTHOR'S CONTRIBUTIONS}

Conception and design: IRI, KRN, NHI; contribution in cell culture works: IRI, KRN; data collection and entry: IRI, FTI; data analysis and interpretation: IRI, FTI; manuscript writing: IRI, FTI; final approval of manuscript: IRI, KRN, FTI, NHI. All authors read and approved the final manuscript.

\section{FUNDING}

None. 


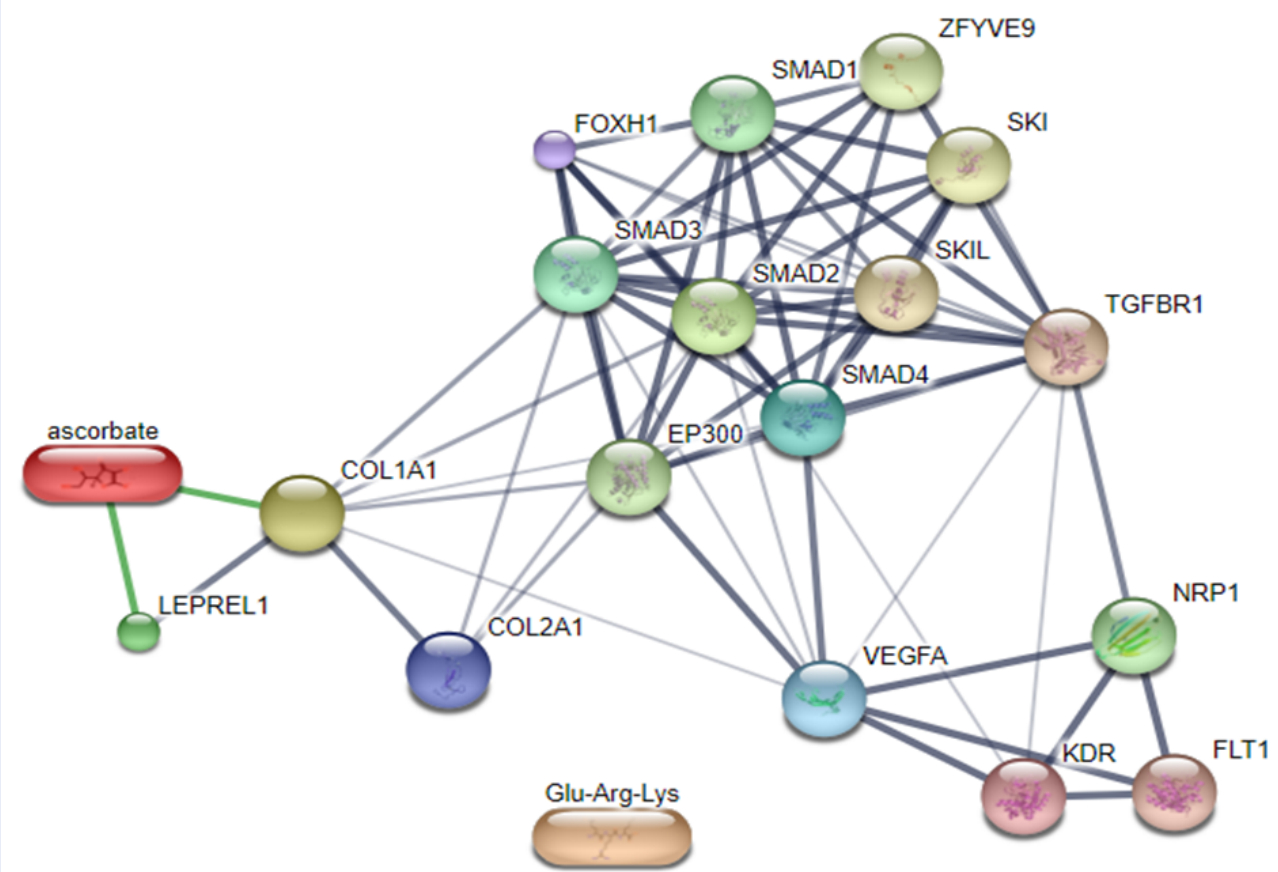

Figure 7: Interaction between ascorbic acid, receptor, and a marker of osteogenesis and chondrogenesis.

\section{AVAILABILITY OF DATA AND MATERIALS}

Data and materials used and/or analyzed during the current study are available from the corresponding author on reasonable request.

\section{ETHICS APPROVAL AND CONSENT TO PARTICIPATE}

The authors are accountable for all aspects of the work in ensuring that questions related to the accuracy or integrity of any part of the work are appropriately investigated and resolved. The study was conducted in accordance with the Declaration of Helsinki (as revised in 2013). The liposuction protocol was approved by the Ethical committee of Dharma Nugraha Hospital (No. 001/SkeI-Kom/RSDN/I/2020) and informed consent was taken from the participant.

\section{CONSENT FOR PUBLICATION}

Not applicable.

\section{COMPETING INTERESTS}

The authors declare that they have no competing interests.

\section{REFERENCES}

1. Rinendyaputri R, Noviantari A. Produksi Mesenchymal Stem Cell (MSC) dari Sumsum Tulang Belakang Mencit. J Biotek Me- disiana Indones. 2015;4(1):33-41. Available from: 10.22435/ jbmi.v4i1.4211.33-41.

2. Ceriana R, Djuwita I, Wresdiyati T. Ekstrak Batang SipatahPatah Meningkatkan Proliferasi dan Diferensiasi Sel Punca Mesenkimal Sumsum Tulang. Jurnal Veteriner. 2014;15(4):436-45.

3. Yahya EB, Alqadhi AM. Recent trends in cancer therapy: A review on the current state of gene delivery. Life Sciences. 2021;269(119087):119087. PMID: 33476633. Available from: 10.1016/j.lfs.2021.119087.

4. Rosadi I, Karina K, Wahyuningsih KA, Rosliana I, Widyastuti T, Sobariah S. Kondrogenesis Adipose-Derived Stem Cells Menggunakan Platelet-Rich Plasma Pada Scaffold Sutra. AlKauniyah J Biol. 2020;13(1):31-8. Available from: 10.15408/ kauniyah.v13i1.12053.

5. Remelia M. Faktor-Faktor yang Mempengaruhi Proliferasi dan Diferensiasi MSC (Mesenchymal Stem Cell) menjadi Sel Kondrosit untuk Pengembangan Terapi Sel Tulang Rawan. CDK223. 2014;41(12):945-947. Available from: (InIndonesian).

6. Rosadi I, Karina K, Rosliana I, Sobariah S, Afini I, Widyastuti $\mathrm{T}$, et al. In vitro study of cartilage tissue engineering using human adipose-derived stem cells induced by platelet-rich plasma and cultured on silk fibroin scaffold. Stem Cell Res Ther. 2019;10:369. PMID: 31801639. Available from: 10.1186/ s13287-019-1443-2.

7. Noviantari A. Khariri. Ragam penelitian dan pengembangan isolasi dan kultur sel punca mesenkim dari berbagai sumber. MASY BIODIV INDON. 2020;6(1):611-8.

8. Katili AS. Struktur Dan Fungsi Protein Dan Enzim. J PELANGI ILMU Vol. 2009;2(5):19-31.

9. Osipyantsa Al, Poloznikova AA, Smirnovaa NA, Hushpuliana DM, Khristichenkoa AY, Chubarb TA, et al. L-ascorbic acid: A true substrate for HIF prolyl hydroxylase? Physiology \& Behavior. 2019;176(3):139-48. 
10. Hasanah U. Penentuan Kadar Vitamin C Pada Mangga Kweni Dengan Menggunakan Metode lodometri. J Kel Sehat Sejah. 2018;16(31):90-5. Available from: 10.24114/jkss.v16i31.10176.

11. Astawa PD, Kawiyana IK, Ridia KG, Astawa P, Suyasa IK, Dusak IW. Pemberian kombinasi kalsium dengan asam askorbat meningkatkan kadar bone alkaline phosphatase dan osteocalcin serum dibanding kombinasi kalsium dengan vitamin d3 pada patah tulang panjang paska fiksasi internal tanpa meningkatkan kadar serum kalsium. Medicina. 2020;51(2):1380-5. Available from: 10.15562/medicina.v51i2. 998.

12. Reang J, Sharma PC, Thakur VK, Majeed J. Understanding the therapeutic potential of ascorbic acid in the battle to overcome cancer. Biomolecules. 2021;11(8):1-24. PMID: 34439796. Available from: 10.3390/biom 11081130 .

13. Karina K, Rosliana I, Rosadi I, Schwartz R, Sobariah S, Afini I, et al. Safety of technique and procedure of stromal vascular fraction therapy: from liposuction to cell administration. Scientifia. 2020;2020:2863624. PMID: 32695550. Available from: $10.1155 / 2020 / 2863624$.

14. Moegni KF, Rosliana I, Remelia M, Rosadi I, Sobariah S, Afini I. Stromal vascular fraction (SVF) therapy for treatment of various diseases: delivering safety of the first patented svf technique in indonesia. Cytotherapy. 2019;21(5):86. Available from: 10.1016/j.jcyt.2019.03.511.

15. Livak KJ, Schmittgen TD. Analysis of relative gene expression data using real-time quantitative $P C R$ and the $2(-\Delta \Delta C(T))$ Method. Methods (San Diego, Calif). 2001;25(4):402-8. PMID: 11846609. Available from: 10.1006/meth.2001.1262.

16. Gandu IV, Budiarso FDH, Kepel BJ. Molecular Docking Senyawa Asam Askorbat dan Kuersetin pada Tumbuhan Jambu Biji Merah (Psidium guajava L.) Sebagai Pencegah COVID-19. J e-Biomedik. 2021;9(2):170-175.

17. Saputra DP. Molecular Docking Sianidin dan Peonidin sebagai Antiinflamasi pada Aterosklerosis Secara In Silico. J Farm
Udayana. 2018;7(1):28. Available from: 10.24843/JFU.2018. v07.i01.p04.

18. Yang M, Su H, Soga T, Kranc KR, Pollard PJ. Prolyl hydroxylase domain enzymes: important regulators of cancer metabolism. Hypoxia. 2014;2:127-42. PMID: 27774472.

19. Culpepper MA, Scott EE, Limburg J. Crystal structure of prolyl 4-hydroxylase from Bacillus anthracis. Biochemistry. 2010;49(1):124-33. PMID: 19947658. Available from: 10.1021/ bi901771z.

20. Pinnell SR. Regulation of collagen biosynthesis by ascorbic acid: a review. The Yale Journal of Biology and Medicine. 1985;58(6):553-9. PMID: 3008449.

21. Pratama AA, Rifai $Y$, Marzuki A. Docking Molekuler Senyawa 5,5'-Dibromometilsesamin. Maj Farm dan Farmakol. 2017;21(3):67-69.

22. Dominici M, Blanc KL, Mueller I, Slaper-Cortenbach I, Marini F, Krause D. Minimal criteria for defining multipotent mesenchymal stromal cells. The International Society for Cellular Therapy position statement. Cytotherapy. 2006;8(4):315-7. PMID: 16923606. Available from: 10.1080/14653240600855905.

23. Rosadi I, Karina K, Rosliana I, Sobariah S, Afini I, Widyastuti T. The effect of human platelet-rich plasma and L-ascorbic acid on morphology, proliferation, and chondrogenesis ability towards human adipose-derived stem cells. Mol Cell Biomed Sci. 2019;3(1):26-33. Available from: 10.21705/mcbs.v3i1.43.

24. Nagao M, Hamilton JL, Kc R, Berendsen AD, Duan X, Cheong CW. Vascular Endothelial Growth Factor in Cartilage Development and Osteoarthritis. Scientific Reports. 2017;7(1):13027. PMID: 29026147. Available from: 10.1038/s41598-017-13417w.

25. Shaw N, Högler W. Chapter 15 - Biochemical Markers of Bone Metabolism. In: Pediatric Bone (Second Edition) Biology \& Diseases. 2018. p. 361-81.;

26. Mansell JP, Bailey AJ. Collagen Metabolism. In: Encyclopedia of Endocrine Diseases. 2004. p. 520-9.; 2004. 
Ready to submit your manuscript? Choose Biomedpress and benefit from:

- Fast, convenient online submission

- Through peer-review by experienced researchers

- Rapid publication on acceptance

- Free of charge (without publication fees)

Learn more http://www.biomedpress.org/journals/
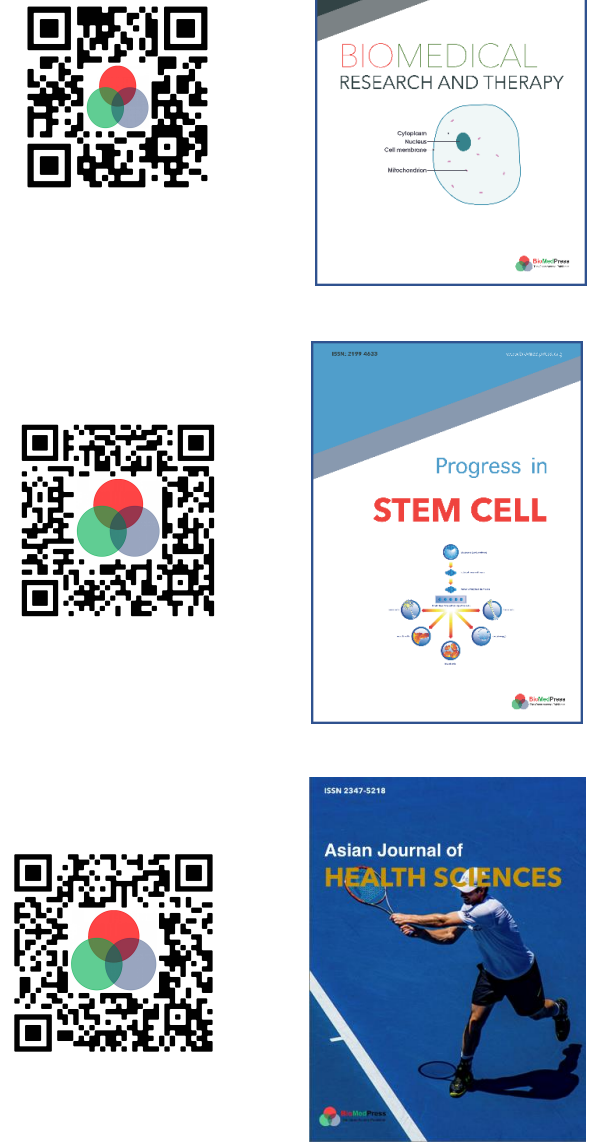

Asian Journal of Health Sciences

ISSN: 2347-5218

Indexed: Google Scholar

Acceptance Rate (2020): 72.89\%

Article Publishing Charge: Free

Submission to first editorial decision: 16.5 days

Biotechnological Research

ISSN: 2395-6763

Indexed: Google Scholar

Acceptance Rate (2020): $67.02 \%$

Article Publishing Charge: Free

Submission to first editorial decision: 28.5 days 